\title{
Assessment of Ambient Air Quality and Air Quality Index (AQI) in Dahej Area, Gujarat, India
}

\author{
Jagrutiben Arunkumar Patel", Bhavesh I. Prajapati and Viralben Panchal \\ College of Renewable Energy and Environmental Engineering, S.D.A.U. \\ Sardarkrushinagar - 385 506, Gujarat, India \\ *Corresponding author
}

\section{A B S T R A C T}

Keywords

Air quality,

Dahej area,

Air quality

Index, CPCB.

Article Info

Accepted:

26 May 2017

Available Online:

10 June 2017
Clean air is basic requirement of living organisms. But now a day, due to the unplanned growth, development and vehicular boom, air becomes polluted. Pollutants of major public health concern include particulate matter, carbon monoxide, ozone, nitrogen dioxide and sulfur dioxide and that can pose a serious threat to human health. In the present study, prime air pollutants $\left(\mathrm{PM}_{10}, \mathrm{PM}_{2.5}, \mathrm{SO}_{2}\right.$ and $\mathrm{NO}_{2}$ ) were estimated in seven stations of Dahej area. The projected value of $\mathrm{PM}_{10}, \mathrm{PM}_{2.5}, \mathrm{SO}_{2}$ and $\mathrm{NO}_{2}$ in all the 7 stations were range from 67.39 to 98.75 , 29.57 to $45.79,17.76$ to 22.29 and 28.29 to $32.42 \mu \mathrm{g} / \mathrm{m}^{3}$, respectively. $\mathrm{PM}_{10}$ level in all stations and $\mathrm{PM}_{2.5}$ level in 3 stations find little higher level than CPCB recommended limit while $\mathrm{SO}_{2}$ and $\mathrm{NO}_{2}$ level were found under permissible limit. AQI values in our study were calculated and it was ranged from 76.50 to 97.75 , which are categorized as satisfactory level by CPCB.

\section{Introduction}

In addition to land and water, air is the prime resource for sustenance of life. For better human health and wellbeing of the humanity, clean air is one of the main basic requirements. Clean air become polluted by variety of sources, out of them household combustion devices, motor vehicles, industrial facilities and forest fires are common sources of air pollution that change the composition of atmosphere and affect the biotic environment. The concentration of air pollutants depend not only on the quantities that are emitted from air pollution sources but also on the ability of the atmosphere to either absorb or disperse these emissions.
The unplanned growth, development and vehicular boom have deteriorated the ambient air quality. Pollutants of major public health concern include particulate matter, carbon monoxide, ozone, nitrogen dioxide and sulfur dioxide and that can pose a serious threat to human health if it exceeds the permissible limit (WHO, 2000; USEPA, 2008). More than two million premature deaths per year can be attributed to the effects of urban (outdoor /indoor) air pollution that is mainly caused by burning of solid fuels (WHO, 2005). More than half of the air pollution driven disease burden is borne by the population of developing countries (WHO, 2005). The 
relationships between the occurrence of respiratory and cardiovascular diseases and cardiopulmonary mortality with exposure to air pollutants are well documented in the literature (Dockery et al., 1994; Koken et al., 2003).

Major source responsible for higher level of SPM, RSPM, $\mathrm{SO}_{2}, \mathrm{NO}_{\mathrm{x}}$ and other organic and inorganic pollutants in environment was motor vehicle emission (Sharma et al., 2006; Jayaraman, 2007; Barman, et al., 2010) and 60 to $70 \%$ of the pollution found in the urban environment is also due to that (Panday et al., 1988; Singh et al., 1995).

The public health implications due to the emission of $\mathrm{CO}, \mathrm{O}_{3}, \mathrm{SO}_{2}, \mathrm{NO}_{2}$ and particulates are very well known (Yadav et al., 2012). Among air pollutants, particulate matter (PM) is a ubiquitous and it's especially a major problem due to its adverse health effect, Visibility reduction and soiling of buildings (Horaginamani and Ravichandran, 2010; Chaurasia et al., 2013).

Central Pollution Control Board initiated National Ambient Air Quality Monitoring (NAAQM) programme in the year 1984 with 7 stations at Agra and Anpara. Subsequently in 1998-99 the programme was renamed as National Air Monitoring Programme (NAMP). The number of monitoring stations under NAMP has increased, steadily, to 295 by 2000-01 covering 98 cities/towns in 29 States and 3 Union Territories of the country. Under NAMP, four air pollutants viz., Sulphur Dioxide $\left(\mathrm{SO}_{2}\right)$, Oxides of Nitrogen as $\mathrm{NO}_{2}$, Particulate Matter $\left(\mathrm{PM}_{2.5}\right)$ and Respirable Suspended Particulate Matter $\left(\mathrm{RSPM} / \mathrm{PM}_{10}\right)$, have been identified for regular monitoring at all the locations.

Air pollution has emerged in the past few decades, pose a critical health problem to the mankind. So, that large number of studies in this regard have been undertaken in all over the World and also in India (Katsouyanni et al., 2001; Afroz et al., 2003; Yang et al., 2004; Samoli et al., 2005; Analitis et al., 2006; Kaushik et al., 2006; Barman et al., 2010; Yadav et al., 2012; Mukhopadhyay and Mukherjee, 2013; Rai et al., 2013; Barman et al., 2015). The aim of the study is to assess the ambient air quality with respect to $\mathrm{PM}_{10}$, $\mathrm{PM}_{2.5}, \mathrm{SO}_{2}$ and $\mathrm{NO}_{2}$ in Dahej area because it is a fast growing industrial area of District Bharuch, Gujarat.

\section{Materials and Methods}

\section{Study area}

Dahej $\left(21^{\circ} \quad 42^{\prime} \mathrm{N}\right.$ and $72^{\circ} \quad 38$ ' $\left.\mathrm{E}\right)$ is a cargo port situated on the South-West coast of Gujarat, India. It is about $45 \mathrm{~km}$ from Bharuch.

\section{Study sites}

The study sites were chosen after proper investigation, based on basic site selection criteria and reduced interference of the local public with the devices used for the experiment. There is seven monitoring stations were chosen in around the Dahej area to measure the concentration of Sulphur dioxide, Nitrogen Dioxide, $\mathrm{PM}_{2.5}$ and $\mathrm{PM}_{10}$ in surrounding environment. The monitoring stations were name as Station-1 (Project Site of Rallis India Ltd), Station-2 (Jolwa Village), Station-3 (Lakigam Village), Station-4 (Rahiyad Village), Station-5 (Jageshwar Village), Station-6 (Suva Village) and Station-7 (Ambetha Village) with station code A 1, A 2, A 3, A 4, A 5, A 6 and A 7, respectively.

\section{Ambient air quality monitoring}

The sample was taken by help of Combo $\mathrm{PM}_{10} \& \mathrm{PM}_{2.5}$ Instrument for $\mathrm{PM}_{10}$ and $\mathrm{PM}_{2.5}$ with air flow rate of $2.3 \mathrm{~m}^{3} / \mathrm{hr}$ and $1.0 \mathrm{~m}^{3} / \mathrm{hr}$ respectively while Gaseous pollutant sampler 
instrument was used for sampling of Sulphur dioxide and Nitrogen Dioxide with specific absorbing solution (Sodium hydroxide \& Sodium arsenite for $\mathrm{NO}_{2}$ and Potassium tetrachloromercuate for $\mathrm{SO}_{2}$ ).

The analysis was carried out in month of December, 2014 to February, 2015 with a frequency of once in a week.

The apparatus was kept at a height of $5 \mathrm{~m}$ from the surface of the ground. Once the sampling was over, the samples were brought to the laboratory and concentration of different pollutants was determined.

The concentration of gases $\mathrm{SO}_{2}$ and $\mathrm{NO}_{2}$ were measured by Modified West and Gaeke method and Modified Jacob Hochheiser method respectively while the particulate pollutants $\mathrm{PM}_{2.5} \& \mathrm{PM}_{10}$ were measured by Gravimetric Method as per prescribed in the Guidelines for Manual Sampling \& Analyses, Central Pollution Control Board (CPCB, 2013; Jacob and Hochheiser, 1958; West and Gaeke, 1956).

The quality of air in the study area can be estimated from the air quality index. There are several methods and equations used for determining the AQI. However, here the below mentioned equation (Zlauddin and Siddiqui, 2006: Joshi and Semwal, 2011) has been used for computation of AQI value.
$\mathrm{AQI}=1 / 4 \times\left(\mathrm{IPM}_{10} / \mathrm{SPM}_{10}+\mathrm{I} \mathrm{PM}_{2.5} / \mathrm{S} \mathrm{PM}_{2.5}\right.$ $\left.+\mathrm{I} \mathrm{SO}_{2} / \mathrm{S} \mathrm{SO}_{2}+\mathrm{INO}_{2} / \mathrm{S} \mathrm{NO}_{2}\right) \times 100$

Where,

$\mathrm{SPM}_{10}, \mathrm{SPM}_{2.5}, \mathrm{SSO}_{2}$ and $\mathrm{SNO}_{2}$ :- represent the new ambient air quality standards as prescribed by the Central Pollution Control Board of India and IPM10, IPM2.5, $\mathrm{ISO}_{2}$ and $\mathrm{SNO}_{2}$ represent the actual values of pollutants obtained on sampling.

\section{Results and Discussion}

The estimated value of air pollutants $\left(\mathrm{PM}_{10}\right.$, $\mathrm{PM}_{2.5}, \mathrm{SO}_{2}$ and $\mathrm{NO}_{2}$ ) of seven stations are presented in Table 1. The projected value of $\mathrm{PM}_{10}, \mathrm{PM}_{2.5}, \mathrm{SO}_{2}$ and $\mathrm{NO}_{2}$ in all the 7 stations were range from 67.39 to $98.75,29.57$ to $45.79,17.76$ to 22.29 and 28.29 to 32.42 $\mu \mathrm{g} / \mathrm{m}^{3}$, respectively.

In the present study, value of $\mathrm{PM}_{10}$ were range from 67.39 to $98.75 \mu \mathrm{g} / \mathrm{m}^{3}$, which was higher than recommended limit $\left(60 \mu \mathrm{g} / \mathrm{m}^{3}\right)$ for residential area as well as industrial area by CPCB in all seven station. The standard limit prescribed by Central Pollution Board of India for $\mathrm{PM}_{2.5}$ for residential area and industrial area was $40 \mu \mathrm{g} / \mathrm{m}^{3}$, but study demonstrated little beat higher level in A 1, A 6 and $\mathrm{A} 7$ area while the concentration of $\mathrm{SO}_{2}$ and $\mathrm{NO}_{2}$ was still under the prescribed limits $\left(50 \mu \mathrm{g} / \mathrm{m}^{3}\right.$ for $\mathrm{SO}_{2}$ and $40 \mu \mathrm{g} / \mathrm{m}^{3}$ for $\left.\mathrm{NO}_{2}\right)$.

Table.1 Estimated Value of Air pollutants $\left(\mathrm{PM}_{10}, \mathrm{PM}_{2.5}, \mathrm{SO}_{2}\right.$ and $\left.\mathrm{NO}_{2}\right)$

In seven station of Dahej area

\begin{tabular}{|c|c|c|c|c|}
\hline Station Code & $\mathrm{PM}_{10} \mu \mathrm{g} / \mathrm{m}^{3}(8 \mathrm{hr})$ & $\mathrm{PM}_{2.5} \mu \mathrm{g} / \mathrm{m}^{3}(8 \mathrm{hr})$ & $\mathrm{SO}_{2} \mu \mathrm{g} / \mathrm{m}^{3}(8 \mathrm{hr})$ & $\mathrm{NO}_{2} \mu \mathrm{g} / \mathrm{m}^{3}(8 \mathrm{hr})$ \\
\hline A 1 & 98.75 & 40.45 & 22.29 & 32.42 \\
\hline A 2 & 76.28 & 30.48 & 20.84 & 30.88 \\
\hline A 3 & 83.82 & 36.67 & 18.73 & 29.17 \\
\hline A 4 & 67.39 & 29.57 & 19.80 & 32.33 \\
\hline A 5 & 78.56 & 33.64 & 17.89 & 31.04 \\
\hline A 6 & 86.70 & 45.79 & 21.59 & 28.79 \\
\hline A 7 & 97.44 & 42.5 & 17.76 & 30.18 \\
\hline
\end{tabular}


Table.2 Air quality category based on AQI of seven station of Dahej area (CPCB)

\begin{tabular}{|l|l|l|}
\hline Station Code & AQI & AQI Category \\
\hline A 1 & 97.75 & Satisfactory \\
\hline A 2 & 82.50 & Satisfactory \\
\hline A 3 & 85.25 & Satisfactory \\
\hline A 4 & 76.50 & Satisfactory \\
\hline A 5 & 82.25 & Satisfactory \\
\hline A 6 & 93.75 & Satisfactory \\
\hline A 7 & 94.75 & Satisfactory \\
\hline
\end{tabular}

The air quality index (AQI) may act as a valuable tool and also act as proxy of ambient air quality status. AQI values in this study were calculated by using the concentration of $\mathrm{PM}_{10}, \mathrm{PM}_{2.5}, \mathrm{SO}_{2}$ and $\mathrm{NO}_{2}$ (by using standard formula mention in material and methods). The AQI value range from 76.50 to 97.75 (Table 2) in seven station of Dahej area, which are categorized as satisfactory level (50 to 100 ) by CPCB. This may cause minor breathing discomfort to sensitive people.

Air pollution in Dahej area was under control level. Level of $\mathrm{PM}_{10}$ in all stations and level of $\mathrm{PM}_{2.5}$ in some locations found beyond the permissible limit but $\mathrm{SO}_{2}$ and $\mathrm{NO}_{2}$ were below the permissible limit at all the stations. Based on the AQI, the Dahej area was categorized as satisfactory, which cause minor breathing discomfort to sensitive people. So, overall air quality of Dahej area was in good condition and it should be maintained for long year, for that the periodic estimation should be carried out to check the level of air pollutants in area.

\section{References}

Afroz R., Hassan M.N., and Ibrahim N.A. 2003. Review of air pollution and health impacts in Malaysia, Environmental research, 92, pp 71-77.

Analitis A., Katsouyanni K., Dimakopoulou K., Samoli E., Nikoloulopoulos A.K., and Petasakis Y. 2006. Short-term effects of ambient particles on cardiovascular and respiratory mortality, Epidemiology, 17(2), pp 230 $-233$.

Barman S.C., Kumar N., and Singh R.2010. Assessment of urban air pollution and its probable health impact, Journal of Environmental Biology, 31(6), pp 913920.

Barman, S. C., Kisku, G. C and Khan, A. H. 2015. Report on "Assessment of ambient air quality of Lucknow city during pre-monsoon, 2015", Environmental Monitoring Division CSIR- Indian Institute of Toxicology Research, M.G. Marg, Lucknow

Barman, S.C., Kumar. N. and Singh, R. 2010. Assessment of urban air pollution and its probable health impact. Journal of Environmental Biolog, 31(6): 913-920

Central Pollution Control Board (CPCB). 2013. Guidelines for Manual Sampling \& Analyses, National Ambient Air Quality Series: NAAQMS/36/2012-13

Chaurasia S, Singh S, Gupta AD. 2013. Study on air quality of SKS Ispat and Power Ltd. Raipur (CG), India. Asian JST 4(4): 48-50.

Dockery D.W. and Pope C.A. 1994. Acute respiratory effects of particulate air pollution. Annu. Rev. Public Health, 15: 107-132,

Horaginamani SM andRavichandran M. 2010. Ambient air quality an urban area and its effects on plants and human beings: 
A case study of Tiruchirappalli, India. Kathmandu Uni. J. Sc. Eng and Tech. 6(2): 13-19.

Jacobs, M.B. and Hochheiser, S. 1958 Continuous sampling and ultra-micro determination of nitrogen oxide in air analyst. Chem 30: 426-428.

Jayaraman, G.N. 2007. Air quality and respiratory health in Delhi. Environ. Monit. Assess, DOI 10.1007/s 10661007-9651-0

Joshi P.C., and Semwal M. 2011. Distribution of air pollutants in ambient air of district Haridwar (Uttarakhad), India: A case study after establishment of State Industrial Development Corporation, International Journal of Environmental Sciences, 2(1), pp 237-243.

Katsouyanni K., Touloumi G., Samoli E., Gryparis A., Le T.A., and Monopolis Y. 2001. Confounding and effect modification in the short-term effects of ambient particles on total mortality: results from 29 European cities within the APHEA2 project, Epidemiology, 12, pp $521-531$.

Kaushik C.P., Ravindra K., and Yadav K. 2006. Assessment of ambient air quality in urban centres of Haryana (India) in relation to different anthropogenic activities and health risk. Environmental monitoring and assessment, 122(1-3), pp 27-40.

Koken P.J., Piver W.T., Ye F., Elixhauser A., Olsen L.M. and Portier C.J. Temperature, air pollution and hospitalization for cardiovascular diseases among elderly people in Denver. Environ. Health Perspect, 111: 1312-1317, (2003).

Mukhopadhyay, S. and Mukherjee, R. 2013.Assessment of ambient air quality of Purulia town, Purulia District, West Bengal, India Biolife, 1(4) : 189-94

Panday, P.K., K.S. Patel and P. Subart. 1988. Trace element composition of atmospheric composition of atmospheric particulate at Bhilai in central east India. Science of total environment, 21 pp 123 - 134.

Rai, P., Panda, L. L., Chutia, B. M. and Singh, M. M. 2013. Comparative assessment of air pollution tolerance index (APTI) in the industrial (Rourkela) and non-industrial area (Aizawl) of India: An eco- management approach, African Journal of Environmental Science and Technology, 7(10): 944-48

Samoli E., Analitis A., Touloumi G., Schwartz J., Anderson H.R., and Sunyer J. 2005. Estimating the exposureresponse relationships between particulate matter and mortality within the APHEA multicity project, Environ health perspect, 113, pp $88-95$.

Sharma, K., Singh, R., Barman, S.C., Mishra, D., Kumar, R., Negi, M.P.S., Mandal, S.K., Kisku, G.C., Khan, A.H., Kidwai, M.M. and Bhargava, S.K. 2006. Comparison of trace metals concentration in PM10 of different location of Lucknow city. Bullet Environ. Contam. Toxicol.77: 419-426

Singh, N., Yonus, M., Srivastav, K., Singh, S.M., and Panday, V. 1995. Monitoring of auto exhaust pollution by road side plant. Environ. Monitor. Asses. 34, pp. 1325.

US Environmental Protection Agency (USEPA). 2008. Air quality index: a guide to air quality and your health. Environmental Protection Agency, Office of Air Quality Planning and Standards, Research Triangle Park.

West, P.W. and Gaeke, G.C. 1956. Fixation of sulphur dioxide as sulfitomercurate (11) and subsequent colorimetric determination. Anal. Chem. 28: 19161819.

World Health Organization (WHO). 2000. Air Quality Guidelines for Europe, 2nd ed., 
Reg. Publ. Eur. Ser., 91: 288, WHO Reg. Off. For Eur., Copenhagen.

World Health Organization WHO. 2005. Air quality guidelines for particulate matter, ozone, nitrogen dioxide and sulfur dioxide. Global update 2005, Summary of risk assessment, WHO/SDE/PHE/OEH/06.02, 2005.

Yadav, S.K, Kumar V, Singh M.M...2012. Assessment of ambient air quality status in urban residential areas of Jhansi city and rural residential areas of adjoining villages of. International Journal of Advanced Engineering Technology III (I):280-285

Yadav, S., Kumar, V. and Singh, M. M. 2012.
Assessment of Ambient Air Quality Status in Urban Residential Areas of Jhansi City and Rural Residential Areas of Adjoining Villages of Jhansi City, International Journal of Advanced Engineering Technology, 3(1): 280-85.

Yang C.Y., Chang C.C., Chuang H.Y., Tsai S.S., Wu T.N., and Ho C.K. 2004. Relationship between air pollution and daily mortality in a subtropical city: Taipei Taiwan, Environment international, 30(4), pp 519-523.

Zlauddin A., and Siddique N.A. 2006. Air quality index (AQI)-A tool to determine ambient air quality, Pollution research, 25, pp 885-887.

\section{How to cite this article:}

Jagrutiben Arunkumar Patel, Bhavesh I. Prajapati and Viralben Panchal. 2017. Assessment of ambient air quality and Air Quality Index (AQI) in Dahej area, Gujarat, India. Int.J.Curr.Microbiol.App.Sci. 6(6): 2714-2719. doi: https://doi.org/10.20546/ijcmas.2017.606.323 